http://journal.nafo.int

J. Northw. Atl. Fish. Sci., Vol. 18: 57-60

\title{
The Nearshore Plankton Holding Zone
}

\author{
H. J. Squires \\ 122 University Avenue \\ St. John's, Newfoundland, Canada A1B 1 Z5
}

\begin{abstract}
Concentration of zooplankton in a holding zone near the shore during onshore winds may be explained hypothetically by the built-in behaviourial responses of planktonic organisms (particularly crustacean larvae) to landwash vibrations. These responses initiate vertical or other migrations which take advantage of compensatory outward currents and keep the plankton from drifting ashore. Lagoon or estuary entrances change the "noise" pattern and the plankton (especially penaeid shrimp or crab larvae) enter the estuary at the deepest part of such channels with inward tidal flows.
\end{abstract}

Key words: Currents, winds, zooplankton.

\section{Introduction}

Living planktonic organisms may drift with the wind but they do not drift ashore. Onshore winds bring big and small particles, inanimate material, to be cast up on the beaches, but living organisms escape this fate. This has been demonstrated on many occasions by examination of the surf area at beaches in different areas by the present author. Even when the heaviest surf was searched repeatedly with a small-meshed hand-net, not a single planktonic copepod or larval crustacean, etc., was caught. Nor was any found with the most careful microscopic examination of the minute debris in the landwash. Particular instances were during the summer of 1962 at Port au Port Bay, Newfoundland (Squires, 1970), a few times at the shore of the Guajira Peninsula, Columbia, South America in 1970, and at Tahuexco, Guatemala in 1984 (Squires et al., 1974; and also Squires, unpublished data (Table 1).

However, when the windstorm died and a boat was launched in Port au Port Bay, for example, a plankton net captured numerous organisms at the surface not far offshore (Squires, 1970). Also in Colombia in 1970 and Guatemala in 1984 plankton concentrations were found in plankton hauls not far offshore when the wind was onshore (Table 1).

The ability of plankton to keep from drifting ashore has considerable importance to the survival of many organisms. Larvae of fishes and crustaceans are examples of planktonic phases of such species. They seem to drift helplessly at the mercy of winds and currents. If they were thrown upon beaches or dashed against the shore they would be killed. They therefore need some defensive mechanism or pattern of behaviour resulting from sensitivity to environmental stimuli to prevent this. It is possible in the evolution of planktonic forms that those without such defences against drifting ashore did not survive. Those that have survived apparently can sense the nearness of the shore or surf zone and have a pattern of behaviour such as migrating downward to take advantage of outward going currents to take them away from the shore.

\section{Plankton entering estuaries or lagoons}

The concentration of crustacean larvae, especially of penaeid shrimps or estuarine crabs, near the shore, and their behaviour with respect to $\mathrm{mi}-$ grating into inflowing currents when the stimulus for avoidance of the shore is lacking, is important to colonizing nursery areas such as lagoons and estuaries, particularly in tropical and subtropical areas where penaeid shrimps develop to adult size in estuaries and lagoons before going to sea to spawn (e.g. Lindner and Anderson (1956)). Camarones Lagoon in the Guajira of Colombia and the estuaries such as at Guapi on the Pacific coast of Colombia are examples. The penaeid shrimps in lagoons and estuaries often form the basis of important artisinal fisheries. Similarly in estuaries such as in Delaware Bay and Chesapeake Bay in the United States (Sandifer, 1975; Dittel et al., 1982; Epifanio et al., 1984), the blue crab, Callinectes sapidus, is able to be exploited in a large industrial fishery.

Work on the distribution of crab larvae near the entrances to Delaware Bay and Chesapeake Bay has demonstrated that concentrations of late stage crab larvae may be found at the bottom near these estuarine areas. It has been shown that these concentrations form a source of recruitment to the estuaries through inflowing currents at the bottom in these areas. Also that recruitment occurs through built-in reactions to flood tides that take the latestage larvae into the estuaries (Sandifer, 1975; Dittel et al., 1982; Epifanio et al., 1984; Olmi, 1994). 
TABLE 1. Observations on nearshore plankton under various wind conditions (number of observations in parentheses).

\begin{tabular}{|c|c|c|c|c|c|c|c|}
\hline Area & Date & $\begin{array}{l}\text { Wind di- } \\
\text { rection } \\
\text { and force }\end{array}$ & $\begin{array}{l}\text { Plankton } \\
\text { organisms } \\
\text { at landwash } \\
\text { Microscopic } \\
\text { exam. of } \\
\text { foam, etc. }\end{array}$ & $\begin{array}{l}\text { Inanimate } \\
\text { material, } \\
\text { small and } \\
\text { large part- } \\
\text { icles at } \\
\text { landwash }\end{array}$ & $\begin{array}{l}\text { Plankton } \\
\text { near land- } \\
\text { wash. No } \\
\text { obvious } \\
\text { concentra- } \\
\text { tion }\end{array}$ & $\begin{array}{l}\text { Plankton } \\
\text { in definite } \\
\text { concentra- } \\
\text { tion not far } \\
\text { from shore }\end{array}$ & $\begin{array}{l}\text { Distance } \\
\text { of net } \\
\text { towing } \\
\text { from } \\
\text { landwash } \\
\text { m est. }\end{array}$ \\
\hline $\begin{array}{l}\text { Port au } \\
\text { Port Bay, } \\
\text { Nfld., } \\
\text { Canada }\end{array}$ & $\begin{array}{l}\text { Aug } \\
1962\end{array}$ & $\begin{array}{l}\text { Onshore } \\
\text { Heavy }\end{array}$ & $\begin{array}{l}\text { None } \\
\text { (23) }\end{array}$ & Numerous & $\begin{array}{l}\text { None } \\
\text { (28) }\end{array}$ & $\begin{array}{l}\text { Yes, at } \\
\text { about } 100 \mathrm{~m} \\
500 \text { lobster } \\
\text { larvae in } \\
10 \text { min tow } \\
\text { (1) }\end{array}$ & $30-150$ \\
\hline $\begin{array}{l}\text { Port au } \\
\text { Port Bay, } \\
\text { Nfld., }\end{array}$ & $\begin{array}{l}\text { Aug } \\
1962\end{array}$ & $\begin{array}{l}\text { Onshore } \\
\text { Offshore } \\
\text { Light }\end{array}$ & $\begin{array}{c}\text { None } \\
\text { (18) }\end{array}$ & $\begin{array}{l}\text { Few } \\
\text { (32) }\end{array}$ & $\begin{array}{c}\text { None } \\
(56)\end{array}$ & $\begin{array}{l}\text { No } \\
(50)\end{array}$ & $20-500$ \\
\hline $\begin{array}{l}\text { Guajira } \\
\text { Peninsula } \\
\text { Colombia } \\
\text { (Caribbean) }\end{array}$ & $\begin{array}{l}12-21 \\
\text { Oct } \\
1970\end{array}$ & $\begin{array}{l}\text { Onshore } \\
\text { Heavy } \\
\text { NE Trades }\end{array}$ & $\begin{array}{l}\text { None } \\
\text { (5) }\end{array}$ & $\begin{array}{c}\text { Many } \\
(23)\end{array}$ & $\begin{array}{c}\text { None } \\
(8)\end{array}$ & $\begin{array}{l}\text { Yes } \\
\text { Also con- } \\
\text { centration } \\
\text { at entrance } \\
\text { to lagoon } \\
1 \text { litre in } \\
2 \text { min tide }\end{array}$ & $100-250$ \\
\hline $\begin{array}{l}\text { Tahuexco, } \\
\text { Guatamala } \\
\text { (Pacific } \\
\text { coast) }\end{array}$ & $\begin{array}{l}6-19 \\
\text { Jun } \\
1984\end{array}$ & $\begin{array}{l}\text { Onshore } \\
\text { Very } \\
\text { light }\end{array}$ & $\begin{array}{c}\text { None } \\
(11)\end{array}$ & $\begin{array}{l}\text { Few } \\
\text { (27) }\end{array}$ & $\begin{array}{c}\text { None } \\
(21)\end{array}$ & $\begin{array}{l}\text { Yes } \\
\text { Mostly } \\
\text { mysids, few } \\
\text { shrimp larvae }\end{array}$ & $30-40$ \\
\hline
\end{tabular}

\section{Previous work on avoidance of shore of plank- tonic organisms}

Siebek (1968) had indicated that Wolterek (1928) was the first to offer an explanation for "uferflucht" or "avoidance of the shore" by planktonic organisms. Wolterek's experiments with small crustaceans in the laboratory and in the field showed that they could sense vibrations of waves in the surf zone and they migrated away from the shore when these vibrations ('noise') reached a sufficient level of intensity. Meanwhile Burckhardt (1910) had explained the absence of plankton near the shore as a result of the vertical migration of organisms. Seeking an appropriate depth with changes in light, or noise at the shore, etc., they migrated down the bottom slope, and when they came to the surface again they were offshore. Being at the surface where feeding is optimal was the usual habitat of these planktonic animals, but they had to avoid drifting ashore when winds were onshore.

Siebeck's (1968) experimental results with small crustaceans in the laboratory showed that they migrated horizontally away from the shore and kept their distance as a negative reaction to the increasing dark image they perceived on the horizon as they drifted towards the shore.
Although the work of Siebeck, Wolterek and others was done on plankton in lakes, the results may nevertheless help to explain events in the sea when onshore winds and waves are strong and the plankton could be destroyed on the shore. Certain reactions of organisms and the action of compensating currents when combined help to keep the plankton from drifting ashore. Nearshore current systems are not considered here in their full complexity. In the surf zone longshore current and rip currents (Bowman and Inmann, 1969) they form a pattern, depending upon the strength of the onshore wind that may reach appreciable distances offshore. Plankton seem to avoid this zone of commotion.

\section{Hypothetical model of plankton behaviour near shore}

A simple model of currents coming in on the surface under force of the wind, and counter currents going out from the shore on the bottom or intermediate levels, may be used to explain how plankton may hold position out and away from the surf (Fig. 1). Whatever the organisms may sense as they drift towards shore, vibrations from breaking waves, darkening of the shoreward horizon, increasing surface motion of the sea etc., a threshold of intensity is reached and they react by migrat- 


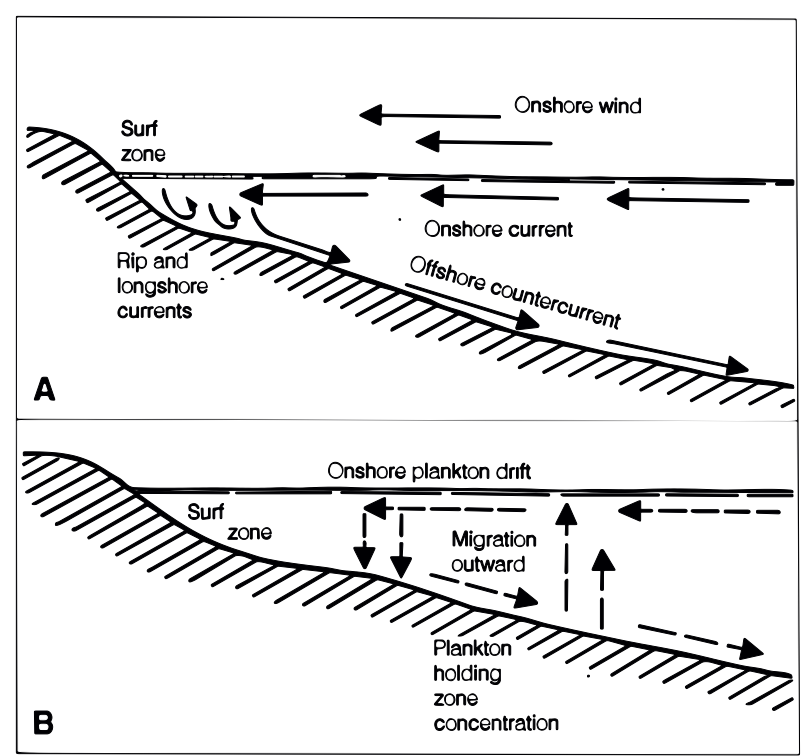

Fig. 1. Diagram of hypothetical nearshore currents under the influence of onshore winds $(\mathbf{A})$, and the plankton holding zone or concentration (B).

ing downward. They are then carried offshore by the counter currents, or they can migrate down the bottom slope where currents are less strong (Fig. 1). Whether they rise again to the surface as the intensity of the vibrations etc., decrease or remain near or on the bottom in preferred depths (Thorson, 1957), they tend to become concentrated in a holding zone not far offshore.

This zone of higher numbers of organisms in the plankton has been demonstrated in our plankton net hauls not far from shore at the surface under light wind conditions following a strong onshore wind. For example, after a severe onshore gale as many as 500 lobster larvae were taken in a single ten minute plankton-net haul near the shore in Port au Port Bay, Newfoundland, on 20 August 1962 (Squires, 1970). When winds were light or offshore, American lobster larvae were never taken in such large numbers: numbers were not more than five larvae in such surface plankton hauls. When winds were offshore it was suggested that larvae probably migrated downward to prevent being swept away from settling grounds (Ennis, 1983).

Both surf and plankton holding zones also change where the shoreline is broken by an entry into a lagoon or estuary (Fig. 2). Apparently when directly off such an entrance the planktonic organisms sense no vibrations of breaking waves etc., from the shore, their escape reactions are inhibited and they are carried towards the entrance. Also the

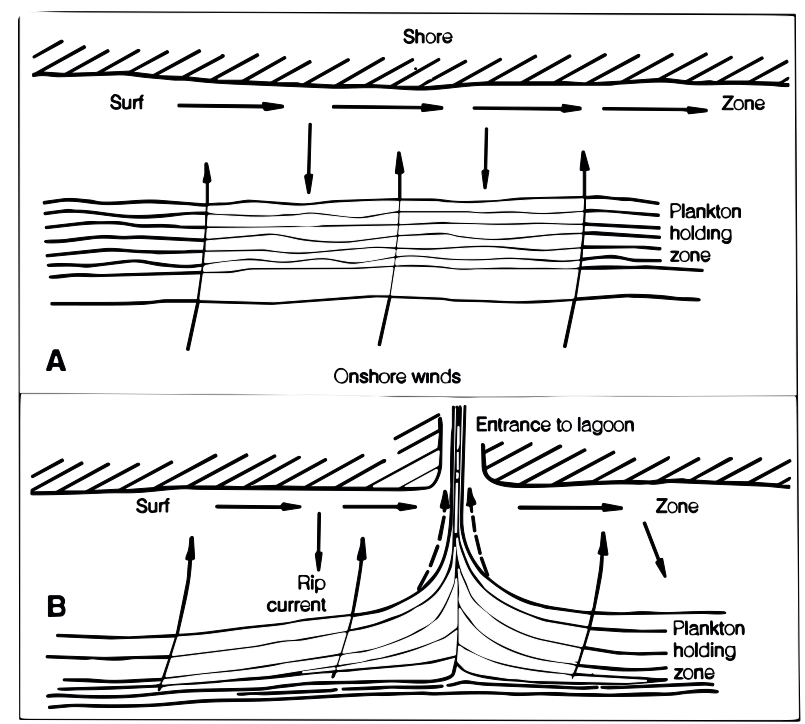

Fig. 2. Diagram of hypothetical plankton holding zone off a lee shore $(\mathbf{A})$, and plankton streaming into a lagoon (B).

deep part of the holding zone may be affected by inflowing tidal bottom currents and the plankton carried in at the centre of the deepest part of the channel. This was demonstrated at the entrance to Mamavita Lagoon at the Guajira Peninsula of Colombia on 15 October 1970 (Squires et al., 1974; Squires, unpublished data) where a plankton net took about one litre of shrimp larvae etc., in a few minutes at the deepest part of the channel. Northeast tradewinds blow on the coast in this area and were fairly heavy (about 20 knots) on this occasion. Surface sweeps of the plankton net took no plankton at the shore (Table 1). Also at the entrance to the lagoon itself no plankton was taken at the surface near the shore, only at the deep part of the channel.

\section{Discussion}

Some aspects of this hypothesis on surf detection and avoidance by planktonic organisms have appeared in the literature. Vertical migration of various planktonic organisms is well known. Whether this is built-in or random behaviour, it often results in the organisms being carried towards shore rather than continuing to drift away from parental grounds in surface currents. Bousfield (1955) demonstrated this in the case of cyprid larvae near an estuary. Rimmer and Phillips (1979) and Phillips and McWilliam (1986) also indicated that phyllosoma larvae of palinurid lobsters may be transported back toward the coast through vertical migration into deep shoreward-moving ocean currents. 
Ennis (1983) gives a review of literature dealing with effects of surface wind drift and vertical migration on distribution of decapod crustacean larvae. Several authors (Sandifer, 1975; Dittel et al., 1982; Epifano et al., 1984) have demonstrated conclusively that decapod larvae take advantage of deep currents entering estuaries by migrating downward and staying in such currents by which they are transported into the estuaries. The concentration of the late stage larvae near the bottom and near the entrance to the estuary seems to be sufficient rationale for their transport. Their built-in responses to environmental stimuli such as light, pressure, sensing the presence of the shore etc., have contributed to their being in the right place at the right time, in an area where they are in considerable numbers and where inflowing bottom currents are present.

Apart from the laboratory work of Wolterek (1928) with small crustaceans, the sensitivity of such organisms to directional vibrations in the water column caused by waves and surf at the shore appears plausible. Phillips and Penrose (1985) hypothesized this for pueruli of spiny lobsters. Also Phillips and MacMillan (1987) identified pennate setae on the antennae of pueruli of Panulirus cygnus which would be able to detect such vibrations.

From these investigations it appears plausible that decapod crustacean larvae have built-in habits of vertical migration, and sensitivity to pertinent environmental stimuli, which mediate to ensure their transport to areas which assure their survival. They are active swimmers, particularly at late larval stages, and are essentially not at the mercy of water currents. Avoidance of shore or migration into estuaries are examples of their adaptations for survival. Other planktonic marine animals undoubtedly have such adaptations also.

\section{Acknowledgements}

I am grateful for the assistance of Gilbert E. Tucker and Frank Jesso for plankton work at the shore in Port au Port Bay in 1962, and to Rolf Bugge, Master Fisherman, and the crew of the research vessel "Choco" in 1970 for assistance with plankton at Mamavita Lagoon, Guajira Peninsula, Colombia, South America. Also to Sherman Bleakney of Acadia University for calling my attention to the work of Siebeck on the avoidance of shore by crustaceans.

\section{References}

BOUSFIELD, E. L. 1955. Ecological control of the occurrence of barnacles in the Miramichi estuary. Nat. Mus. Can. Bull., 137: 69 p.

BOWMAN, A. J., and D. L. INMANN. 1969. Rip currents. Laboratory and field observations. J. Geophys. Res.,
74(23): 5479-5490.

BURCKHARDT, G. 1910. Hypothesen und Beobachtungen uber die Bedeutung der vertikalen Planktonwanderung. Int. Rev. Hydrobiol., 3: 156-172.

DITTEL, R., A. I. EPIFANIO, and C. E. EPIFANIO. 1982. Seasonal abundance and vertical distribution of crab larvae in Delaware Bay. Estuaries, 5: 197-202.

ENNIS, G. P. 1983. The effect of wind direction on the abundance and distribution of decapod crustacean larvae in a Newfoundland nearshore area. Can. Tech. Rep. Fish. Aquat. Sci., 1138: iv + $19 \mathrm{p}$.

EPIFANIO, C. E., C. C. VALENTI, and A. E. PEMBROKE. 1984. Dispersal and recruitment of blue crab larvae in Delaware Bay, U.S.A. Estuarine, Coastal and Shelf Sci., 18: 1-12.

LINDNER, M. J., and W. W. ANDERSON. 1956. Growth, migrations, spawning and size distribution of shrimp Penaeus setiferus. Fish. Bull. U.S., 56: 555-645.

OLMI III, E. J. 1994. Vertical migration of blue crab, Callinectes sapidus megalopae; implication for transport in estuaries. Mar. Ecol. Prog. Ser., 113: 39-54.

PHILLIPS, B. F., and D. L. MACMILLAN. 1987. The antennal receptors in puerulus and post-puerulus stages of the rock lobster Panulirus cygnus (Decapoda, Palinuridae) and their potential role in puerulus navigation. J. Crustacean Biol., 7: 122-135.

PHILLIPS, B. F., and P. S. MCWILLIAM. 1986. The pelagic phase of spiny lobster development. Can. J. Fish. Aquat. Sci., 43: 2153-2163.

PHILLIPS, B. F., and J. D. PENROSE. 1985. The puerlus stage of the (rock) spiny lobster and its ability to locate the coast. School of Physics and Geosciences, Western Australian Institute of Technology Report No. SPG 374/1985/AP92.

RIMMER, D. W., and B. F. PHILLIPS. 1979. Diurnal migration and vertical distribution of phyllosoma of western rock lobster, Panulirus cygnus George. Mar. Biol., 54: 109-124.

SANDIFER, P. A. 1975. The role of pelagic larvae in recruitment to populations of adult decapod crustaceans in the York River estuary and adjacent lower Chesapeake Bay, Virginia. Estuarine and Coastal Mar. Sci., 3: 269-279.

SIEBECK, O. 1968. "Uferflucht" und optische Orientierung pelagischer Crustaceen. Archiv für Hydrobiologie.

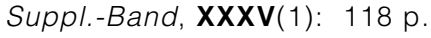

SQUIRES, H. J. 1970. Lobster (Homarus americanus) fishery and ecology in Port au Port Bay, Newfoundland, 1961-65. Proc. Nat. Shellfish. Assoc., 60: 22-39.

SQUIRES, H. J., L. I. BUCHELLI, B. HERAZO, S. A. TESTAVERDE, and G. RIVEROS. 1974. Cruceros para camarones y langostas en la costa del Caribe Colombiano por el B/I CHOCO en 1970. Divulgacion Pesquera (INDERENA, Bogota, Colombia), 11(3): 1-15.

THORSON, G. 1957. Bottom communities (sublittoral or shallow shelf). In: Treatise on Marine Ecoology and Palaecology, J. W. Hedgpeth (ed.), Vol. 1. Geol. Soc. America Mem., 67: 461-534.

WOLTEREK, R. 1928. Uber die speziftat des Lebensraumes der Nahrung und der Korpenformen bei pelagischen Cladoceren und uber "okologische Gestalt-Systeme". Biol. Zbl., 48: 521-551. 